\title{
Bawean Island: The Potential for Ecotourism and Local Knowledge on Plant Diversity Supporting Ecotourism
}

\author{
Trimanto*, Setyawan Agung Danarto, Siti Nurfadilah \\ Purwodadi Botanic Garden-Indonesian Institute of Sciences, Pasuruan, Indonesia
}

\begin{abstract}
Bawean Island has attractive biodiversity and natures that are potential for development. The present study was aimed to investigate (i) the potential of Bawean Island's natural resources for ecotourism (ii) local knowledge of Bawean people on plant diversity and uses, and (iii) the potential of plants for commodities supporting ecotourism development. The potential of Bawean Island for ecotourism was examined based on data of attractive natural environments, while the local knowledge was obtained by interviewing Bawean people and observation of the daily practical use of plants. Various plants were analysed for their potential as commodities suppporting ecotourism. The results showed that Bawean Island has high potential resources for ecotourism. It is ranging from beaches, mountains, rivers, plant diversity, and endemic animals. The local knowledge showed that Bawean has plant diversity with various potential uses. There were 81 plant species traditionally used by Bawean people, including plants for foods ( 40 species), ornamental plants (15 species), timbers for housings and buildings ( 9 species), medicines (8 species), natural dyes (4 species), and other uses (5 species). Various plant species potential as the commodity supporting ecotourism development included Abelmoschus manihot (traditional food), Diospyros discolor (fresh local fruit), Nypa fruticans and Pandanus tectorius (local handicrafts), Phalaenopsis amabilis (ornamental plants or cutting flowers). The use of plants in Bawean Island needs to consider the sustainable use of plants and conservation approaches.
\end{abstract}

Keywords: Bawean, conservation, ecotourism, local knowledge, plant diversity.

\section{INTRODUCTION*}

Bawean Island is a small island located between Java and Kalimantan. It has many attractive natural environments and resources include Solomon River, Ria Beach, Tanjung Ori Beach, Pacinggahan Beach, Mayangkara Beach, Bangkuang Mountain, Laccar Waterfall, and Bawean Deer Sanctuary that are potential in the development of Bawean for ecotourism. Various natural sources such as mountains, forests, plateaus, shores, lakes, rivers and the diversity of flora and fauna are known as a part of ecotourism sources [1].

The principles of ecotourism are based on the sustainable tourism with awareness to natural environment protection and conservation; the increase of economic growth of local community; and community social progress $[2,3,4]$. With the attractive natural environment and sources and people resources, Bawean Island is potential to be developed as ecotourism.

Bawean is also endowed with plant diversity that has many potential uses. Local knowledge on plant diversity is important to increase

\footnotetext{
${ }^{*}$ Correspondence address:

Trimanto

Email : triman.bios08@gmail.com

Address : Purwodadi Botanic Garden-Indonesian Institute of Sciences, Jl.Surabaya-Malang Km. 65 Purwodadi Pasuruan, East Java, Indonesia 67163
}

understanding of the uses of plants based on the empirical experience of the people and to improve the utility of the plants that can be developed as commodities that support the development of ecotourism in Bawean.

Local knowledge is knowledge and beliefs that are embedded in community practice, based on experience that are transmitted through generations $[5,6]$. Local knowledge is related to ethno botany that explores the relationships between people and plants, and the environments [7]. Plants are a part of biological resources for human beings that can be used to obtain the benefits and to supply all basic needs (food, health, and industrial products) [6]. Research on ethno botany that explore the local knowledge of the indigenous people on plants has been widely conducted, such as in Sumatra [7], Kalimantan [8], Jambi [9], Maluku [10], even across the world; such as in North America [11], Nigeria [12], Russia [13], Pakistan [14], and India [15].

Plant diversity and uses can be used to support the development of ecotourism. Various plant species that have unique uses can be developed as commodities in the development of ecotourism in Bawean, such as traditional food and handicrafts.

The aims of the present study were to investigate (i) the potential of Bawean Island for ecotourism, (ii) local knowledge of Bawean 
people on plant diversity and use, (iii) the potential of plants for commodities supporting ecotourism development. The general aims of the present study were to support Bawean for ecotourism and to increase awareness of conservation and socio-economic progress of Bawean people as well as the conservation of plant diversity in Bawean through sustainable use of the plants to support the development of ecotourism in Bawean.

\section{METHODS}

The potential of Bawean Island (Fig.1) for ecotourism was analysed by exploring attractive natural environments in Bawean including beaches, rivers, waterfalls, lakes, and sanctuaries. This exploration was through direct observation and visit to the natural environments and through data from website.

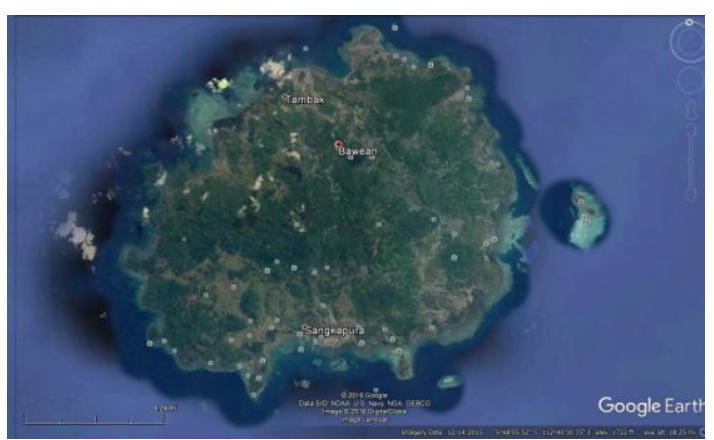

Figure 1. Bawean Island (Source: Google Earth)

The local knowledge of Bawean people was investigated through interview, questionnaire, freelisting, and direct observation. Focus of the investigation was the use of plants in local people daily life in Bawean. The study was conducted in two districts in Bawean, Tambak and Sangkapura [16]. Respondents were randomly sampled in several villages in both districts Tambak and Sangkapura. Several villages sampled were Patar Selamat, Pudakit Barat, Pudakit Timur, Dekat Agung, Bulu Lanjang (Sangkapura), Tanjung Ori, Paromaan, Tambak (Tambak). Total of sampled respondents were 100 adults. The interviews were conducted by asking several information of plants, the use, how to use, and how to cultivate or propagate the plants.

Direct observation was conducted on how to use the plants and how to cultivate some particular plants. Cultivated plants were observed in Bawean people's home gardens. Wild plants used by Bawean people were also observed the wild (forest area in Bawean). Field survey was supported by elder Bawean people who have local knowledge about the wild plants. Each sample of ethnobotanical plant specimen was documented. Data were analysed descriptively. The potential of plants that can be developed as commodities to support ecotourism in Bawean was analysed through selection of the uniqueness of the plants and their uses.

\section{RESULT AND DISCUSSION The Potential of Bawean for Ecotourism}

The results showed that Bawean has many natural environments that are potential in ecotourism development (Table 1). There are several attractive natural environments in $\mathrm{Ba}$ wean including beaches (Fig. 2), lake, waterfall, sanctuary, mountains (Fig. 3) and small island near Bawean island. Some beaches in Bawean such as Ria beach, Mayangkara Beach, Kuburan Panjang beach, and Tanjung Gaang beach with their white sands are important objects for the ecotourism development. Apart from beaches, there are Kastoba lake, Laccar waterfall, Bawean deer sanctuary (Fig. 4), and small island near Bawean. These can support ecotourism development in Bawean.

Table 1. Natural Environments in Bawean for the Development of Bawean for Ecotourism

\begin{tabular}{|c|c|c|}
\hline No & $\begin{array}{c}\text { Natural } \\
\text { environments }\end{array}$ & Products of ecotourism \\
\hline 1 & Ria beach & Beach \\
\hline 2 & Mayangkara beach & Beach \\
\hline 3 & $\begin{array}{l}\text { Kuburan Panjang } \\
\text { beach }\end{array}$ & Beach; mangrove forest \\
\hline \multirow[t]{3}{*}{4} & Tanjung Gaang & Beach \\
\hline & $\begin{array}{l}\text { Tanjung Anyar } \\
\text { beach }\end{array}$ & Beach; prawn farming \\
\hline & Tanjung Ori beach & Beach \\
\hline 5 & $\begin{array}{l}\text { Kastoba lake } \\
\text { (protected area) }\end{array}$ & $\begin{array}{l}\text { Lake; primary forests, flora, } \\
\text { fauna }\end{array}$ \\
\hline 6 & Nypa forest & Nypa forest \\
\hline 7 & Solomon River & river \\
\hline 8 & $\begin{array}{l}\text { Gunung Panjang } \\
\text { Mountain } \\
\text { (protected area) }\end{array}$ & $\begin{array}{l}\text { Forest, flora with the domi- } \\
\text { nant flora Ficus variegata, } \\
\text { Irvingia malayana; endemic } \\
\text { pig, deer, protected areas }\end{array}$ \\
\hline 9 & $\begin{array}{l}\text { Bangkuang } \\
\text { Mountain } \\
\text { (protected area) }\end{array}$ & $\begin{array}{l}\text { Mountain, forest, flora and } \\
\text { fauna }\end{array}$ \\
\hline 10 & $\begin{array}{l}\text { Mandala Mountain } \\
\text { (protected area) }\end{array}$ & $\begin{array}{l}\text { Mountain, forest, flora and } \\
\text { fauna, with the dominant } \\
\text { flora Fagraea fragrans }\end{array}$ \\
\hline 11 & Laccar waterfall & waterfall \\
\hline 12 & $\begin{array}{l}\text { Bawean deer } \\
\text { sanctuary }\end{array}$ & $\begin{array}{l}\text { Sanctuary of endemic deer of } \\
\text { Bawean }\end{array}$ \\
\hline 13 & Gili Island & Small island near Bawean \\
\hline 14 & Noko island & Small island near Bawean \\
\hline 15 & Noko Selayar island & Small island near Bawean \\
\hline
\end{tabular}




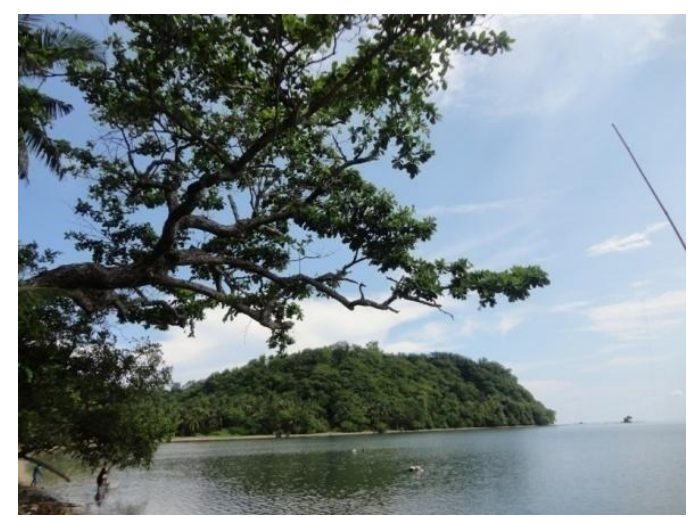

Figure 2. View of Tanjung Anyar Beach in Bawean

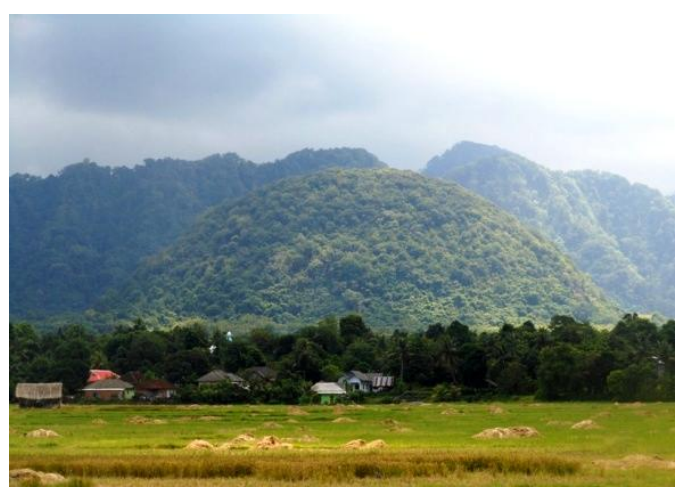

Figure 3. One of Beatiful Views of Mountains in Bawean

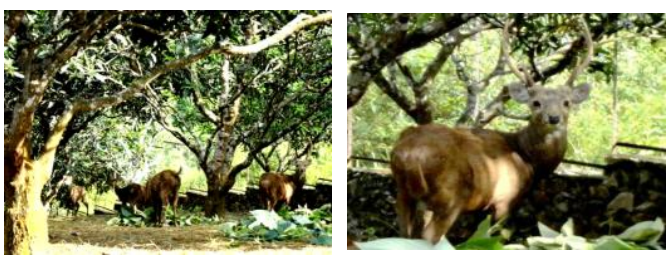

Figure 4. The Sanctuary of Endemic Deer of Bawean

In line with the definition of ecotourism that was coined by Ceballos Lascurain in 1993 that ecotourism is a journey to visit and enjoy natural environments that hold principles on the conservation and minimum visitor impacts, and increase the involvement of local community for their socio-economic progress, the plans of the development of Bawean for ecotourism should be made by involving the local authorities government and the local community. Appropriate policy for ecotourism is required to protect environment for conservation, to lower adverse impacts of visitors, and to regulate the involvement of the local people in the development of ecotourism $[17,18,19]$.

\section{Local Knowledge of Plant Diversity and Uses}

The present study also showed the local knowledge of Bawean people on the plant diversity and uses. Based on the data of interviewing Bawean people, there were 81 plant species used by Bawean people for various purposes in their daily life. Commonly, Bawean people conducted conservation approaches in using the plants, through plant cultivation for the sustainable use of the plants, especially plants that have important values, such as plants that are potential as food resources. They grew the plants in the home yards or fields around their houses. A large area of rice field is located near settlements.

The patterns of the use of plants by Bawean people can be categorised as plants for consumption, medicines, timbers for housings or buildings, ornamental plants, natural dyes, and other uses (Fig. 5; Table 2-9). The majority of plants (40 species) were used by Bawean people for consumption (staples, vegetables, and fruits). The proportion of the use of the plants for food resources is the highest (Fig. 5).

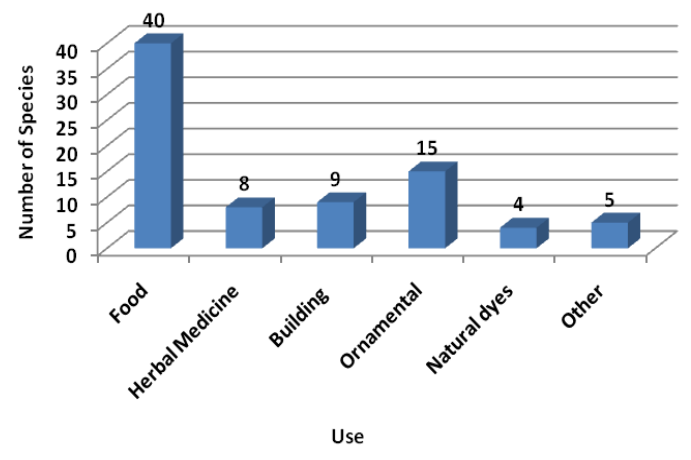

Figure 5. Number of Plants Species Traditionally Used by Bawean People

Based on the place in which the plants grow, the plants can be categorised as (i) the wild species and (ii) the cultivated species (Fig 6). Bawean people mostly used cultivated plant species (69 species; $85 \%$ ) compared to the wild ones (12 species; $15 \%$ ).

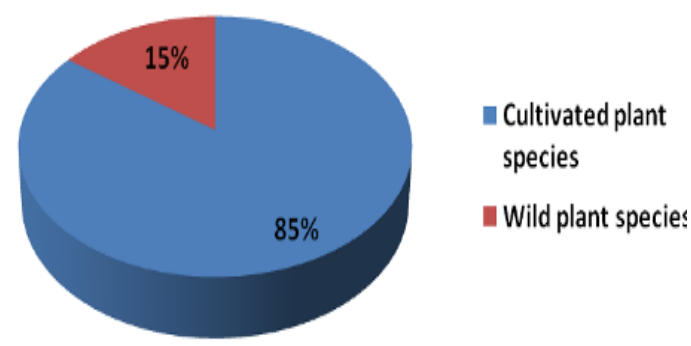

Figure 6. Percentage of Wild Plant Species and Cultivated Plant Species Traditionally Used by Bawean People 
The highest proportion on the use of plants by Bawean people is for consumption or as food resources. Fourty one plant species often used for food has been documented. The use of these plants are for main food (staples), fruits, vegetables, and flavors, etc. Rice (Oryza sativa) is the main food source (staple) of Bawean people, therefore, the majority of fields are planted with rice. Romo variety is the most chosen rice variety by Bawean people (Fig. 7). Many Bawean people grow rice for their own need of food. Our observation on the rice cultivation by Bawean people showed that the cultivation methods they used was simple and classic including the system of the application of fertilisers, the management of treatments of pests and diseases, and inefficient methods of harvesting. Therefore, the yields from rice harvesting is not optimal. Best management practices for high yield rice needs to be introduced and practiced in Bawean. Other plant species used as food alternatives are corns (Zea mays), Canna indica, sweet potatoes (Ipomoea batatas), Xanthosoma sagittifolium, etc. Food source from tuber-producing plants can be potentially developed in this island as the typical soil in this island is relatively loamy and dry.

Various plant species were also consumed for fruits (Table 2). These commodities are vital for Bawean people as Bawean Island is far from other places. To meet the basic needs on fruits and vegetables, Bawean people grow some plants as the source of fruits (Table 3) and vegetables (Table 4) for their own consumption. Banana is a popular fruit in this island. At least more than 10 banana cultivars we found in Bawean island, such as banana Elang, Molin, Lampeneng, Klombu, Sanah, Kismis, Keleng, Kepok, Sepet, Alas, Biji, Kapal, Sobo, etc. They cultivated these bananas in their garden. Some mango cultivars were also grown in this island. Other local fruits that we found were Diospyros discolor, Limonia acidissima (Kawista), Psidium guajava (guava), Manilkara zapota (sawo kecik), Salacca zalacca (salacca). Local fruits are also commodities for sale in their traditional markets.
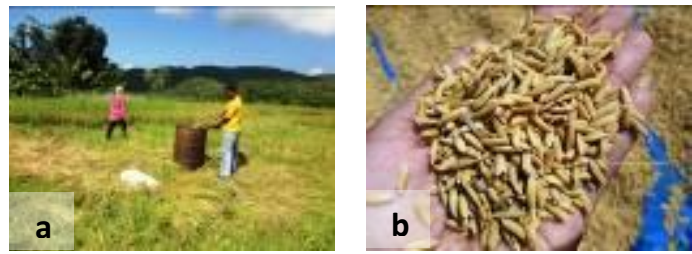

Figure 7. Rice Cultivation in Bawean Island a) Traditional rice cultivation by Bawean people; b) Romo variety, the most chosen rice variety in Bawean Island

Some vegetables are grown in the home yard or in the field and used for daily consumption. The characteristic vegetables of Bawean people are sayur kacang lendir made from (Abelmoschus manihot) that are cooked in soup. Other vegetables often consumed were the stolon of Colocasia esculenta, Vigna unguiculata, Sesbania sesban, Psophocarpus palustris, Muntingia calabura, and Momordica angustisepala. Some plants were grown for spices and cooking ingredients such as celeries, chilies, tomatoes, cumins, and other plants of a family Zingiberaceae, etc. The availability of vegetable plants in their homes are important as the price of vegetables in the markets is relatively expensive. The various food sources in Bawean Island are potential for food diversification, which is important for the sustainable food security in this island on the basis of the diversity of Bawean local food source.

Table 2. The Use of Plants for Food

\begin{tabular}{|c|c|c|c|c|c|}
\hline No & Latin Name & $\begin{array}{l}\text { Vernacular } \\
\text { Name }\end{array}$ & Family & Uses & Categories \\
\hline 1 & Canna indica & Ganyong & Cannaceae & $\begin{array}{l}\text { The tubers are boiled for consumption } \\
\text { and as the carbohydrate source. }\end{array}$ & Cultivated \\
\hline 2 & Dioscorea hispida & Gadung & Dioscoreaceae & The tubers can be cooked for crackers & Wild \\
\hline 3 & Ipomoea batatas & Ketela & Convolvulaceae & $\begin{array}{l}\text { The tubers can be cooked by boiling or } \\
\text { can be processed to make crackers }\end{array}$ & Cultivated \\
\hline 4 & Oryza sativa & Padi & Poaceae & $\begin{array}{l}\text { The rice seeds are the main food source } \\
\text { (staple) of Bawean people }\end{array}$ & Cultivated \\
\hline 5 & $\begin{array}{l}\text { Xanthosoma } \\
\text { sagittifolium }\end{array}$ & Patet & Araceae & The tubers are cooked by steaming & Cultivated \\
\hline 6 & Zea mays & Jagung & Poaceae & $\begin{array}{l}\text { The fruits are used as the main food } \\
\text { source that can be cooked by steaming or } \\
\text { processed as corn flour }\end{array}$ & Cultivated \\
\hline 7 & Cucurbita moschata & Waluh & Cucurbitaceae & $\begin{array}{l}\text { Ripe fruits can be boiled or steamed for } \\
\text { consumption }\end{array}$ & Cultivated \\
\hline 8 & Manihot esculenta & Singkong & Euphorbiaceae & The tubers can be consumed by boiling & Cultivated \\
\hline
\end{tabular}


Table 3. The Use of Plants for Fruit

\begin{tabular}{|c|c|c|c|c|c|}
\hline No & Latin Name & $\begin{array}{l}\text { Vernacular } \\
\text { Name }\end{array}$ & Family & Uses & Categories \\
\hline 1. & Ananas comosus & Nanas & Bromeliaceae & Ripe fruits can be directly consumed & Cultivated \\
\hline 2. & Annona muricata & Sirsak & Annonaceae & Ripe fruits can be directly consumed & Cultivated \\
\hline 3. & Blighia sapida & $\begin{array}{l}\text { Mahkota } \\
\text { dewa cina }\end{array}$ & Sapindaceae & $\begin{array}{l}\text { Seeds can be directly consumed and function as } \\
\text { medicinal plants }\end{array}$ & Cultivated \\
\hline 4. & Carica papaya & Pepaya & Caricaceae & $\begin{array}{l}\text { Young fruits can be used as vegetables that are } \\
\text { cooked and ripe fruits can be directly consumed }\end{array}$ & Cultivated \\
\hline 5. & $\begin{array}{l}\text { Chrysophyllum } \\
\text { cainito }\end{array}$ & Buah susu & Sapotaceae & Fresh fruits can be directly consumed & Cultivated \\
\hline 6. & Cucumis sativus & Timun & Cucurbitaceae & $\begin{array}{l}\text { The ripe fruits can be directly consumed (fresh } \\
\text { vegetables) }\end{array}$ & Cultivated \\
\hline 7. & $\begin{array}{l}\text { Diospyros } \\
\text { discolor }\end{array}$ & Buah merah & Ebenaceae & Ripe fruits can be directly consumed & Wild \\
\hline 8. & Durio zibethinus & Duren & Malvaceae & Ripe fruits can be directly consumed & Cultivated \\
\hline 9. & $\begin{array}{l}\text { Limonia } \\
\text { acidissima }\end{array}$ & Kawista & Rutaceae & $\begin{array}{l}\text { Fruits can be directly consumed or for fruit } \\
\text { punch. }\end{array}$ & Wild \\
\hline 10. & Mangifera indica & Mangga & Anacardiaceae & Ripe fruits can be directly consumed & Cultivated \\
\hline 11. & Manilkara zapota & Sawo & Sapotaceae & Ripe fruits can be directly consumed & Cultivated \\
\hline 12. & Musa acuminata & Pisang molen & Musaceae & Ripe fruits can be directly consumed & Cultivated \\
\hline 13. & Psidium guajava & Jambu merah & Myrtaceae & Ripe fruits can be directly consumed & Cultivated \\
\hline 14. & Salacca zalacca & Salak & Arecaceae & Ripe fruits can be directly consumed & Cultivated \\
\hline 15. & $\begin{array}{l}\text { Muntingia } \\
\text { calabura }\end{array}$ & Kerten & Muntingiaceae & Ripe fruits can be directly consumed & Cultivated \\
\hline 16. & $\begin{array}{l}\text { Theobroma } \\
\text { cacao }\end{array}$ & Cokelat & Malvaceae & $\begin{array}{l}\text { The seeds are used as the source of the main } \\
\text { components of chocolates }\end{array}$ & Cultivated \\
\hline
\end{tabular}

Table 4. The Use of Plants for Vegetables

\begin{tabular}{|c|c|c|c|c|c|}
\hline No & Latin Name & $\begin{array}{l}\text { Vernacular } \\
\text { Name }\end{array}$ & Family & Uses & Categories \\
\hline 1. & $\begin{array}{l}\text { Abelmoschus } \\
\text { manihot }\end{array}$ & $\begin{array}{l}\text { Kacang } \\
\text { lendir }\end{array}$ & Malvaceae & Young fruits are cooked with soup & Cultivated \\
\hline 2. & Apium graveolens & Celeries & Apiaceae & Leaves as flavors in dishes & Cultivated \\
\hline 3. & Averrhoa bilimbi & $\begin{array}{l}\text { Blimbing } \\
\text { wuluh }\end{array}$ & Oxalidaceae & $\begin{array}{l}\text { The fruits can be added into vegetable } \\
\text { sour soup }\end{array}$ & Cultivated \\
\hline 4 & $\begin{array}{l}\text { Boesenbergia } \\
\text { rotunda }\end{array}$ & Temu kunci & Zingiberaceae & $\begin{array}{l}\text { The tubers can be used for cooking } \\
\text { ingridients }\end{array}$ & $\begin{array}{l}\text { Wild and } \\
\text { Cultivated }\end{array}$ \\
\hline 5 & Capsicum annuum & Cabe & Solanaceae & The fruits are used as cooking ingridients & Cultivated \\
\hline 6 & Cocos nucifera & Kelapa & Arecaceae & $\begin{array}{l}\text { Ripe coconut fruits for coconut milk and } \\
\text { the young ones for fresh drinks. }\end{array}$ & Cultivated \\
\hline 7 & $\begin{array}{l}\text { Plectranthus } \\
\text { amboinicus }\end{array}$ & Jinten & Lamiaceae & Used for spices & Cultivated \\
\hline 8 & $\begin{array}{l}\text { Colocasia } \\
\text { esculenta }\end{array}$ & Jangkar & Araceae & $\begin{array}{l}\text { The stolon can be used as vegetables and } \\
\text { can be cooked. The tubers can be directly } \\
\text { consumed by boiling. }\end{array}$ & Cultivated \\
\hline 9 & $\begin{array}{l}\text { Cymbopogon } \\
\text { nardus }\end{array}$ & Serai & Poaceae & Old leaves for cooking ingridients & Cultivated \\
\hline 10 & Ipomoea aquatica & Kangkung & Convolvulaceae & $\begin{array}{l}\text { The leaf tips / young leaves as the } \\
\text { vegetables sources that can be cooked }\end{array}$ & Cultivated \\
\hline 11 & Luffa acutangula & Gambas & Cucurbitaceae & fruits are cooked with soup & Cultivated \\
\hline 12 & $\begin{array}{l}\text { Momordica } \\
\text { angustisepala }\end{array}$ & Pare welut & Cucurbitaceae & $\begin{array}{l}\text { Young fruit peels can be used for cooked } \\
\text { vegetables }\end{array}$ & Cultivated \\
\hline 13 & $\begin{array}{l}\text { Psophocarpus } \\
\text { palustris }\end{array}$ & Kecipir & Leguminosae & $\begin{array}{l}\text { Young fruits can be used for vegetables } \\
\text { sources that can be mildly fried or for } \\
\text { soup }\end{array}$ & Cultivated \\
\hline 14 & Sesbania sesban & Taroe & Leguminosae & Flowers for vegetables & Cultivated \\
\hline 15 & $\begin{array}{l}\text { Solanum } \\
\text { lycopersicum }\end{array}$ & Tomat & Solanaceae & $\begin{array}{l}\text { Ripe fruits for consumption or for cooking } \\
\text { ingridients }\end{array}$ & Cultivated \\
\hline 16 & Vigna unguiculata & Otok & Leguminosae & $\begin{array}{l}\text { Young fruits are used as cooked } \\
\text { vegetables }\end{array}$ & Cultivated \\
\hline
\end{tabular}


Bawean people have a modern life style, therefore, doctors and hospitals are the first destination to go when they are sick. However, some Bawean people also use some plant species as herbal medicines to maintain their fitness or when they are sick. Those plants are planted in their home yard, such as Benincasa hispida usually used to prevent from a sore throat (pharyngitis), Rhinacanhtus nasutus for external application for itchy skin and used for stomachache, Sauropus androgynus used for fevers. Citrus aurantiifolia and Piper crocatum were used to treat cough and wounds, respectively (Table 5 ).

The structure of house of most Bawean people, except, people living near forests and beaches, has been modern. The structure of house in the town is from concrete materials, while houses of people living near forests and beaches were built from woods and timbers. The diversity of plants by Bawean people living near forests is used for housings and furnitures (Table 6). A variety of woody plants (trees) is often used for the parts of houses such as house pillars and roofs. Some plant species used for buildings and furnitures are directly collected from forests. Irvingia malayana is mostly chosen by Bawean people as the local timbers for the structure of house pillars and roofs. Irvingia malayana was a dominant plant in the forest. it is favourite feed of endemic deer Axis kuhlii [20]. Many people also grew other woody plants such as Swietenia mahagoni (mahoni), Tectona grandis (teak) and Gmelina arborea (white teak). The abundance of leaves of Nypa fruticans near the beach was used for the roofs of huts in the rice fields and farms.

Table 5. The Use of Plants for Herbal Medicines

\begin{tabular}{|c|c|c|c|c|c|}
\hline No & Latin Name & $\begin{array}{l}\text { Vernacular } \\
\text { Name }\end{array}$ & Family & Use & Categories \\
\hline 1 & Benincasa hispida & Koaden & Cucurbitaceae & $\begin{array}{l}\text { Young fruits for vegetables, candies, fruit } \\
\text { jams, and juices to cure a sore throat } \\
\text { (pharyngitis) }\end{array}$ & Cultivated \\
\hline 2 & Citrus aurantiifolia & Jeruk pecel & Rutaceae & $\begin{array}{l}\text { The slices of fruits are poured in the hot } \\
\text { water to cure cough }\end{array}$ & Cultivated \\
\hline 3 & $\begin{array}{l}\text { Graptophyllum } \\
\text { criptum }\end{array}$ & Daun ungu & Acanthaceae & $\begin{array}{l}\text { The leaf extracts for decoction and drink } \\
\text { as antianemia (increase red blood cells } \\
\text { and } \mathrm{Hb} \text { ) }\end{array}$ & Cultivated \\
\hline 4 & Oroxylum indicum & Kayu lanang & Bignonaceae & The roots are used as hair tonicum & Cultivated \\
\hline 5 & Piper crocatum & Sirih & Piperaceae & $\begin{array}{l}\text { The leaves are used to cure wounds, by } \\
\text { chewing the leaves and apply the chewed } \\
\text { leaves to the wounds. }\end{array}$ & Cultivated \\
\hline 6 & Punica granatum & Delima putih & Lythraceae & $\begin{array}{l}\text { The fruits are blended with curcuma and } \\
\text { drink to cure a sore throat (pharyngitis) }\end{array}$ & Cultivated \\
\hline 7 & $\begin{array}{l}\text { Rhinacanthus } \\
\text { nasutus }\end{array}$ & $\begin{array}{l}\text { Cucuk } \\
\text { manuk }\end{array}$ & Acanthaceae & $\begin{array}{l}\text { The flowers are boiled and the extract } \\
\text { water was drunk for stomachache }\end{array}$ & Cultivated \\
\hline 8 & $\begin{array}{l}\text { Sauropus } \\
\text { androgynus }\end{array}$ & Katu & Phyllanthaceae & $\begin{array}{l}\text { The leaves are used for vegetables for } \\
\text { lactation and antipyretic }\end{array}$ & Cultivated \\
\hline
\end{tabular}

Table 6. The Use of Plants for Housings / Buildings

\begin{tabular}{|c|c|c|c|c|c|}
\hline No & Latin Name & $\begin{array}{l}\text { Vernacular } \\
\text { Name }\end{array}$ & Family & Uses & Categories \\
\hline 1 & Bambusa vulgaris & Bambu & Poaceae & The stems for timber for housing & Wild \\
\hline 2 & Canarium oleosum & Kenari & Burseraceae & The stems for timber for housing & Wild \\
\hline 3 & Ficus variegata & Gondang & Moraceae & The stems for timber for housing & Wild \\
\hline 4 & Gmelina arborea & Jati putih & Lamiaceae & $\begin{array}{l}\text { The stems for timber for housing, and the } \\
\text { leaves for the feed of Bawean deers }\end{array}$ & Cultivated \\
\hline 5 & Irvingia malayana & Kayu buluh & Irvingiaceae & $\begin{array}{l}\text { The stems for timber for housing, the } \\
\text { fruits for snacks by putting the fruits on } \\
\text { hot pans in a short time, and the leaves } \\
\text { for the feed of Bawean deers }\end{array}$ & Wild \\
\hline 6 & Leea angulata & Kayu besi & Vitaceae & The stems for timber for housing & Wild \\
\hline 7 & Nypa fruticans & Nipah & Arecaceae & The leaves are used for the house roofs & Wild \\
\hline 8 & $\begin{array}{l}\text { Swietenia } \\
\text { mahagoni }\end{array}$ & Mahoni & Meliaceae & The stems for timbers for housing & Cultivated \\
\hline 9 & Tectona grandis & Jati & Lamiaceae & The old stems for timbers for housing & Cultivated \\
\hline
\end{tabular}


The use of plants by Bawean people to decorate their house was unique. The people loved to make their home more beautiful and artistics, therefore, many plant species were used for house decoration, such as orchids. The orchids were collected from the forests, such as Phalaenopsis amabilis and Dendrobium anosmum. Plant species that have colourful flowers are the choice of Bawean people to make their home cosy and beautiful, such as Euphorbia milii, Mirabilis jalapa, and Ixora coccineae. Crotons such as Codiaeum variegatum are also chosen as they have glossy multicolored foliage and it is easy to plant them. The needs of ornamental plants (Table 7) are also important for Bawean people. However, there was no cultivation or propagation of ornamental plants in Bawean island.

The use of plants by Bawean people for natural dyes was for colouring foods, such as cakes or dishes (Table 8). Curcuma longa with its natural yellow is usually used for cooking karee. This plant species is sometimes used for herbal medicines. For green colour for the cakes and and pastries, people use the extracts of leaves of Pandanus amaryllifolius and Dracaena angustifolia. Lawsonia inermis is used for nail dyes. The plants used for dyes are usually grown in the home yards. Wild plants in the forests are useful for important animals in Bawean island, such as Tacca palmata being the feed source for birds. Groundcover plants such as grasses, ferns, and herbs, also ripe fruits falling from forest trees being the feed source of the Bawean endemic deers. Some plant species were also cultivated for the feed source of the deers in the sanctuary. Other uses of plants are for handicrafts, such as Pandanus for mats, handicrafts (Table 9).

The sustainable use of plants by Bawean people through daily use and propagation or cultivation in a large number for daily uses (Fig. 8 ) in long terms is one act of conservation as this can increase the chance of plants to survive. The known functions of the plant species for people daily lives can increase the awareness of people for the availability of plants all the times. Thus, it can reduce the risk of plants to become extinct.

Table 7. The Use of Plants for Ornamental Plants

\begin{tabular}{|c|c|c|c|c|c|}
\hline No & Latin Name & $\begin{array}{l}\text { Vernacular } \\
\text { Name }\end{array}$ & Family & Uses & Categories \\
\hline 1 & Adenium obesum & Kamboja & Apocynaceae & Ornamental plants with beautiful flowers & Cultivated \\
\hline 2 & Canna hybrida & & Cannaceae & Ornamental plants & Cultivated \\
\hline 3 & $\begin{array}{l}\text { Codiaeum } \\
\text { variegatum }\end{array}$ & Puring & Euphorbiaceae & Ornamental plants with colourful leaves & Cultivated \\
\hline 4 & Cordyline fruticosa & Andong & Asparagaceae & $\begin{array}{l}\text { Ornamental plants with its colourful } \\
\text { beautiful leaves }\end{array}$ & Cultivated \\
\hline 5 & Crescentia cujete & Buah Mojo & Bignonaceae & The plants for house border fences & Cultivated \\
\hline 6 & $\begin{array}{l}\text { Dendrobium } \\
\text { anosmum }\end{array}$ & Anggrek & Orchidaceae & The flowers for home interior decoration & Wild \\
\hline 7 & Dypsis lutescens & Palem kuning & Arecaceae & The plants for fences in front of houses & Cultivated \\
\hline 8 & Euphorbia milii & & Euphorbiaceae & $\begin{array}{l}\text { Ornamental plants as they flower whole the } \\
\text { year }\end{array}$ & Cultivated \\
\hline 9 & Ficus elastica & & Moraceae & Ornamental plants & Cultivated \\
\hline 10 & Helianthus annuus & Bunga matahari & Compositae & Ornamental plants with its beautiful flowers & Cultivated \\
\hline 11 & Ixora coccinea & Soka & Rubiaceae & The plants for home interior decoration & Cultivated \\
\hline 12 & Livistona chinensis & Palem hias & Arecaceae & $\begin{array}{l}\text { Ornamental plants that are planted in front } \\
\text { of houses }\end{array}$ & Cultivated \\
\hline 13 & Mirabilis jalapa & Conderet & Nyctaginaceae & $\begin{array}{l}\text { Ornamental plants with beautiful yellow } \\
\text { flowers }\end{array}$ & Cultivated \\
\hline 14 & Nerium oleander & Bunga mentega & Apocynaceae & Ornamental plants & Cultivated \\
\hline 15 & $\begin{array}{l}\text { Phalaenopsis } \\
\text { amabilis }\end{array}$ & Anggrek bulan & Orchidaceae & The flowers for home interior decoration & Wild \\
\hline
\end{tabular}

Table 8. The Use of Plants for Natural Dyes

\begin{tabular}{|c|c|c|c|c|c|}
\hline No & Latin Name & $\begin{array}{l}\text { Vernacular } \\
\text { Name }\end{array}$ & Family & Uses & Categories \\
\hline 1 & Curcuma longa & Kunyit & Zingiberaceae & The stolons are extracted used as dyes & Cultivated \\
\hline 2 & Lawsonia inermis & Pacar kuku & Lythraceae & The leaves for fingernails dyes & Cultivated \\
\hline 3 & $\begin{array}{l}\text { Pandanus } \\
\text { amaryllifolius }\end{array}$ & Pandan wangi & Pandanaceae & $\begin{array}{l}\text { The old leaves are extracted as food coloring } \\
\text { for cakes or breads }\end{array}$ & Wild \\
\hline 4 & $\begin{array}{l}\text { Dracaena } \\
\text { angustifolia }\end{array}$ & Pandan betawi & Asparagaceae & $\begin{array}{l}\text { The old leaves are extracted and added with } \\
\text { water as food coloring }\end{array}$ & Cultivated \\
\hline
\end{tabular}


Table 9. Other Uses of Plants


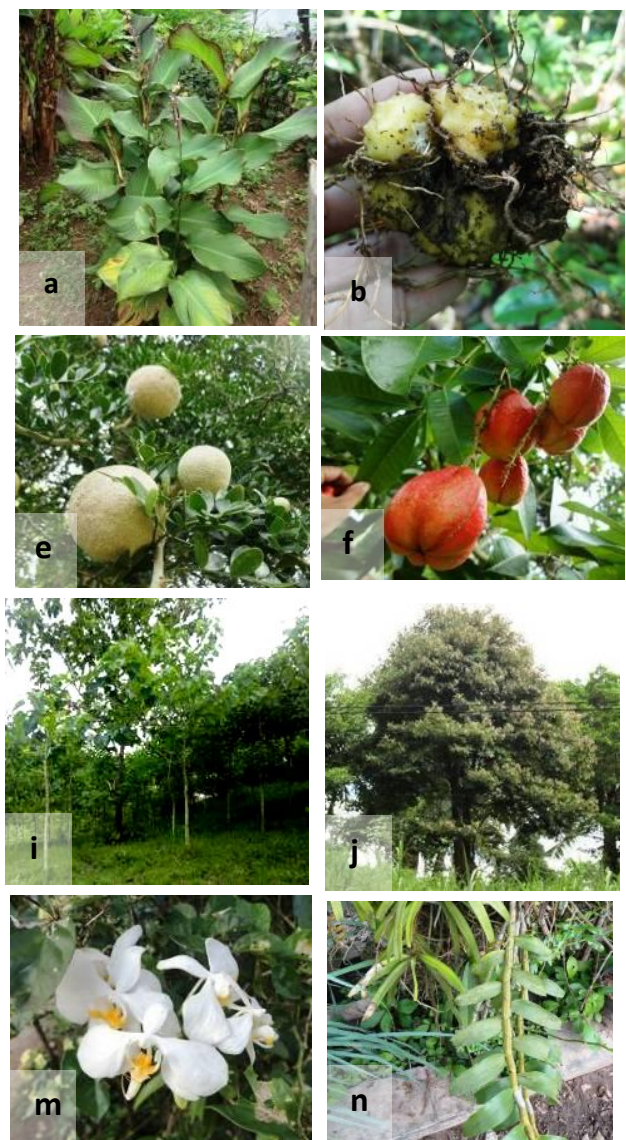
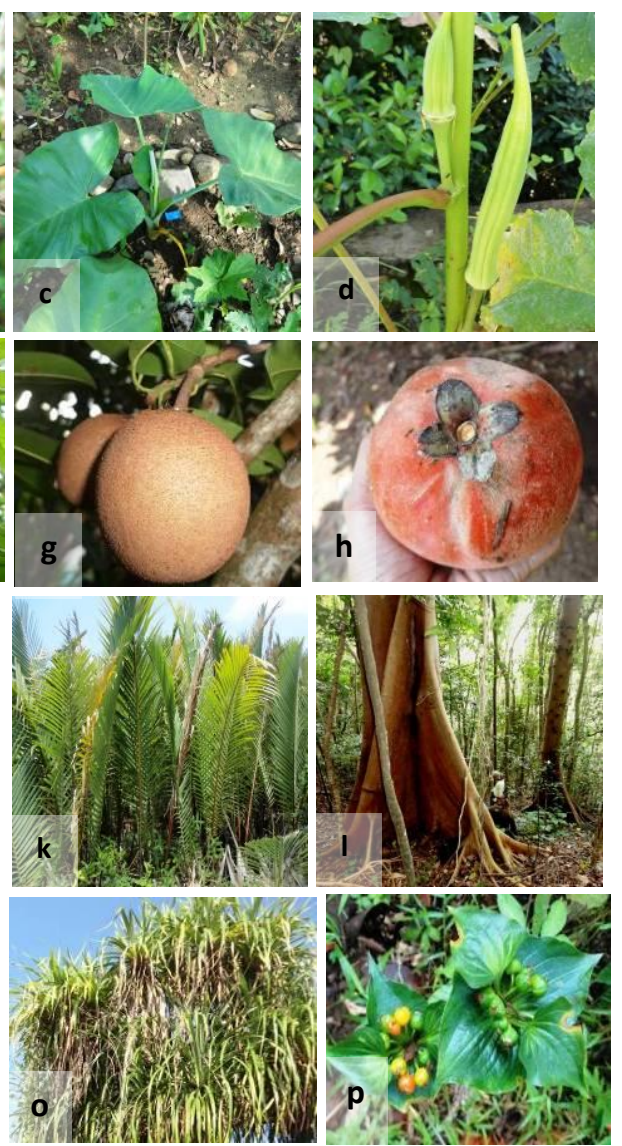

Figure 8. Daily Used Plants in Bawean Island; a)Canna indica, b)Dioscorea hispida, c)Xanthosoma sagittifolium, d)Abelmoschus manihot, e)Limonia acidissima, f)Blighia sapida, g) Manilkara zapota, h)Diospyros discolor, i)Gmelina arborea, j)Irvingia malayana, k) Nypa fruticans, I) Ficus variegata, m) Phalaenopsis amabilis, n)Dendrobium anosmum, o) Pandanus tectorius, $p$ ) Tacca palmata

We can learn from Bawean people, that in some parts, they consider conservation aspects in using plants in their daily lives through the use of cultivated plants, for the food source and herbal medicines. However, in the use of plants for housings or buildings, some Bawean people, especially people living near the forests, directly collected the woody plants from the forests and conducted logging in forest areas. These can threat the survival of woody plants and lead to the forest damages. Conservation of woody plants and forests needs to be considered to be as the main priority. Conservation through cultivation or plantation of woody plants needs to be created (i) to meet the needs and demands for timbers for housings and (ii) for forest rehabilitation purposes. This conservation program needs to be socialized to Bawean people.

The present study on the local knowledge of Bawean provides information of the various uses of plant diversity. This confirms the essential role and the importance of plants for human beings as the plants are the source of foods, herbal 
medicines, building materials, ornamental plants, and other vital uses.

The Potential of Plants for the Commodity Supporting Ecotourism Development in Bawean

There are some plants that are potential to be developed as commodities to support ecotourism in Bawean, such as traditional food and souvenirs (Table 10). Bawean island has traditional food, kacang lendir, which is made from Abelmoschus manihot. This is potential to be developed as commodities as Bawean traditional food that can be sold to support ecotourism in Bawean. Some fresh local fruits are also potential commodities for ecotourism, such as Diospyros discolor, Manilkara zapota, Musa acuminata, and Limonia acidissima. Limonia acidissima can also be processed for syrups as commodities. Local handicrafts as the characteristic of Bawean, such as local mats and hats made from Nypa fruticans and Pandanus tectorius, are also potential to be developed as commodities for ecotourism in Bawean (Table 10). Musa acuminata and Dioscorea hispida can be processed for crackers that can be sold to support ecotourism development. Dioscorea is used by locally people in east java especially in Nganjuk and it is easy to be cultivated [21]. Phalaenopsis amabilis and Dypsis lutescens are potential to be developed as commodities of ornamental plants.

Table 10. Some Plant Species Potential to be Developed as Commodities Supporting Ecotourism in Bawean

\begin{tabular}{|c|c|c|}
\hline No & Plant species & Commodities potential \\
\hline 1 & Abelmoschus manihot & $\begin{array}{l}\text { Traditional food } \\
\text { (kacang lendir) }\end{array}$ \\
\hline 2 & $\begin{array}{l}\text { Diospyros discolor } \\
\text { (buah merah) }\end{array}$ & Fresh local fruit \\
\hline 3 & Manilkara zapota & Fresh local fruit \\
\hline 4 & Musa acuminata & $\begin{array}{l}\text { Fresh fruits, crackers, } \\
\text { traditional food (getuk) }\end{array}$ \\
\hline 5 & Dioscorea hispida & Crackers \\
\hline 6 & Limonia acidissima & Syrup \\
\hline 7 & Nypa fruticans & Local handicrafts, \\
\hline 8 & Pandanus tectorius & $\begin{array}{l}\text { Local handicrafts, } \\
\text { traditional rugs/mats, }\end{array}$ \\
\hline 9 & Phalaenopsis amabilis & $\begin{array}{l}\text { Ornamental plants or } \\
\text { cutting flowers }\end{array}$ \\
\hline 10 & Dypsis lutescens & Ornamental plants \\
\hline 11 & Irvingia malayana & $\begin{array}{l}\text { Tour service in Bawean } \\
\text { deer sanctuaries by } \\
\text { feeding the deers with } \\
\text { leaves of } I . \text { malayana }\end{array}$ \\
\hline
\end{tabular}

Bawean island has a distinctive sanctuary with its endemic deer. The feed of the deers is leaves of Irvingia malayana. This species can be developed as the feed source for the deers and can be a part of tour service of feeding the deers with its leaves in the sanctuary to support the ecotourism development (Table 10).

The involvement of local community in Bawean is important to support the production of those commodities for the development of ecotourism in Bawean. It can benefits the local community by increasing their income and to support the socio-economic progress in Bawean.

The production of those commodities that are sourced from plants needs to consider conservation of the plant species. The plant materials used in the production should not be harvested from forests as it can decrease the population of plant species in their natural habitat and threaten the existence of the plants. The plants that are used for the production of those commodities should come from propagation that can regenerate a large number of plants.

\section{CONCLUSION}

Bawean island with its attractive natural environments is potential for ecotourism. The local knowledge of the Bawean people on plant diversity and uses is important to increase understanding of the potential uses of plants and the potential for the development of plants for commodities that can support ecotourism in Bawean.

\section{ACKNOWLEDGEMENTS}

This reserach was supported by DIPA Grant of Purwodadi Botanic Garden - Indonesian Intitute of Sciences.

\section{REFERENCES}

[1]. Yilmaz, O. 2011. Analysis of the potential for ecotourism in Gölhisar district. Procedia Social and Behavioral Sciences 19, 240-249

[2]. Wood, M. E. 2002. Ecotourism: principles, practices, and policies for sustainabiity. United Nations Publication.

[3]. Roos, S. and G. Wall. 1999. Ecotourism: towards congruence between theory and practice. Tourism Management 20, 123132.

[4]. Kiper, T. 2013. Role of ecotourism in sustainable development. In: Ozyavuz, M. (Ed.). Advances in Landscape Architecture. InTech. Available at: http://www.intech open.com/books/advances-in-landscapearchitecture/role-of-ecotourism-insustainable-development. 
[5]. Warburton and Martin. 1999. What is local knowledge? Food and Agriculture Organization of the United Nations. Rome.

[6]. Nordic Council of Ministers. 2015. Local knowledge and resource management on the use of indigenous and local knowledge to document and manage natural resources in the Arctic. Denmark.

[7]. Choudhary, K., M. Singh and U. Pillai. 2008. Ethnobotanical survey of Rajasthan - an update. American-Eurasian Journal of Botany 1 (2), 38-45.

[8]. Waluyo, E. B. 2011. Sumbangan ilmu etnobotani dalam memfasilitasi hubungan manusia dengan tumbuhan dan lingkungannya. Jurnal Biologi Indonesia 7(2), 375-391

[9]. Simbolon, H. 1994. Ethnobotany of people around the Dolok Sibual-Buali Nature Reserve Area, North Sumatra, Indonesia. Tropics 4(1), 69-78

[10]. Koizumi, M. 2000. Ethnobotany of the Penan Benalui of East Kalimantan, Indonesia: Difference of Ethnobotanical Knowledge Among Villagers of Long Belaka. African Study Monographs 29, 53-60.

[11]. Hariyadi, B. and T. Ticktin, 2012. Uras: medicinal and ritual plants of Serampas, Jambi, Indonesia. Ethnobotany Research and Applications 10, 133-149.

[12]. Ellen, R. O. Y. 2006. Local knowledge and management of sago palm (Metroxylon sagu Rottboell) diversity in South Central Seram, Maluku, Eastern Indonesia. Journal of Ethnobiology 26(2), 258-298

[13]. Karst, A. 2010. Conservation value of the North American Boreal Forest from an ethnobotanical perspective. Canadian Boreal Initiative, David Suzuki Foundation and Boreal Songbird Initiative. Ottawa.

[14]. Ezuruike, U. F. and J. M. Prieto. 2014. The use of plants in the traditional management of diabetes in Nigeria: Pharmacological and toxicological considerations. Journal of Ethnopharmacology 155, 857-924.

[15]. Shikov, A. N., O. N. Pozharitskaya, V. G. Makarov, H. Wagner, R. Verpoorte, M. Heinrich. 2014. Medicinal Plants of the Russian Pharmacopoeia; their history and applications. Journal of Ethnopharmacology 154, 481-536

[16]. Ibrar, M., F. Hussain and A. Sultan. 2007. Ethnobotanical studies on plant resources of Ranyal Hills, District Shangla, Pakistan. Pakistan Journal of Botany 39(2), 329-337

[17]. Jaafar, M. and S. A. Maideen. 2012. Ecotourism-related products and activities, and the economic sustainability of small and medium island chalets. Tourism Management 33, 683-691.

[18]. Coria, J. and E. Calfucura. 2012. Ecotourism and the development of indigenous communities: The good, the bad, and the ugly. Ecological Economics 73, 47-55.

[19]. Ioppolo, G., G. Saija, R. Salomone. 2013. From coastal management to environmental management: The sustainable eco-tourism program for the mid-western coast of Sardinia (Italy). Land Use Policy 31, 460- 471

[20]. Trimanto, T. 2014. Analisis vegetasi dan estmasi biomassa stok karbon pada tujuh hutan gunung Suaka Alam Pulau Bawean Jawa Timur. Berita Biologi 13(3), 321-332.

[21]. Trimanto, T. and L. Hapsari. 2015. Diversity and utilization of Dioscorea spp. tuber as food source in Nganjuk Regency, East Java. Agrivita 37(2), 97-107. 